\title{
Diagnostic tests to assess balance in patients with spinal cord injury: a systematic review of their validity and reliability
}

\author{
Aatik Arsh ${ }^{1 * \odot}$, Haider Darain ${ }^{\circledR}$, Irfan Ullah ${ }^{2 \odot}$, Syed Shakil-ur-Rehman ${ }^{\circledR \odot}$
}

\section{Abstract}

Background: Sophisticated biomechanical instruments can assess balance in patients with spinal cord injury (SCI) with accuracy and precision; however, they are costly and time consuming to use. Clinical diagnostic tests to assess balance in patients with SCI are less costly and easier to use, but there is limited literature available regarding their reliability and validity.

Objectives: To review systematically articles reporting the validity and reliability of diagnostic tests used to assess balance function in patients with SCI.

Methods: We searched for articles in the English language from the earliest record to December 15, 2020, which reported validity or reliability of any clinical instrument or diagnostic test used to assess balance in patients with SCI. Articles assessing balance in paraplegic patients with causes other than SCI were excluded. Databases included MEDLINE, AMED, EMBASE, HMIC, PsycINFO, CINAHL, Scopus, and Google Scholar. The COSMIN Risk of Bias checklist was used to assess the studies included and PRISMA-DTA guidelines were applied.

Results: We included 16 articles that assessed the validity or reliability of 10 diagnostic tests. The Functional Reach Test (FRT), Berg Balance Scale (BBS), and Mini-Balance Evaluation Systems Test (Mini-BESTest) were assessed by more than 1 study, while the remaining 7 diagnostic tests including the Function in Sitting Test, T-Shirt Test, Motor Assessment Scale item 3, Sitting Balance Score, 5 Times Sit-to-Stand Test, Tinetti scale, and Sitting Balance Measure were assessed by 1 study each. The FRT has good-to-excellent test-retest reliability, excellent inter-rater reliability, and good construct, concurrent, and convergent validity. The BBS has excellent inter-rater and intra-rater reliability, high internal consistency, and good concurrent and construct validity. The Mini-BESTest has excellent test-retest reliability, excellent inter-rater reliability, high internal consistency, and good concurrent, convergent, and construct validity.

Conclusions: The FRT, BBS, and Mini-BESTest appear to be valid and reliable clinical instruments to assess balance function in patients with SCI.

Keywords: diagnostic test; outcome assessment, health care; postural balance; reproducibility of results; spinal cord injuries

Balance function or postural stability is important for performing activities of daily living [1]. Balance function is necessary, even for performing simple tasks such as sitting, standing, and walking. Similarly, complex motor skills, such as running, jumping, and dancing, also depend on efficient balance control [2]. Balance control is achieved through the

*Correspondence to: Aatik Arsh, Institute of Physical Medicine and Rehabilitation, Khyber Medical University, Khyber Pakhtunkhwa 25100, Peshawar, Pakistan, email: aatikarsh@kmu.edu.pk

'Institute of Physical Medicine and Rehabilitation, Khyber Medical University, Peshawar, Khyber Pakhtunkhwa 25100, Pakistan

${ }^{2}$ Kabir Medical College, Gandhara University, Peshawar, Khyber Pakhtunkhwa 25000, Pakistan

${ }^{3}$ Riphah College of Rehabilitation and Allied Health Sciences, Riphah International University Lahore, Punjab 54000, Pakistan

Ә Open Access. ๑ 2021 Arsh et al., published by Sciendo. (c) BY-Nc-ND This work is licensed under the Creative Commons Attribution NonCommercial-NoDerivatives 4.0 License. 
integration of sensory inputs, the central processing system, and neuromuscular response. Sensory inputs include visual, vestibular, and proprioceptive inputs; the central processing system includes the brain and spinal cord, while neuromuscular responses include motor control [3]. Disturbance in any of the systems that maintain normal balance function will result in impaired balance [4].

Neurological disorders almost always result in impaired balance. Although the main disturbance in these neurological conditions is present in central processing system, the neuromuscular response and sensory inputs are also disturbed to some extent in these disorders [5]. Like those with other neurological disorders, individuals with spinal cord injury (SCI) also have poor balance function. In individuals with SCI, proprioception, the central processing system, and neuromuscular response are disturbed, which leads to an array of complications [6]. Although individuals with complete SCI remain wheel chair bound and only sitting balance is important for them, individuals with incomplete SCI need balance for both standing and sitting [7].

Because balance problems are known to disrupt rehabilitation and prevent patients with neurological conditions from performing activities of daily living, rehabilitation specialists always focus on balance function $[8,9]$. Without appropriate balance training, individuals with SCI mostly remain bed bound and never function as productive members of society [10]. Many interventions and exercises are applied to manage balance problems in patients with SCI and almost all of them improve balance function to some extent [11]. Clinicians are always interested in making objective measurements of the improvement occurring as a result of therapeutic intervention and for this purpose they use clinical assessment or diagnostic tools [12].

Assessment of balance function in clinical settings is a daunting task. Many biomechanical instruments are available to assess balance function with accuracy and precision in patients with SCI; however, these sophisticated biomechanical instruments are usually not appropriate for use in clinical settings [13]. For research purposes, balance assessment is performed by measuring the center of pressure, forces, torques, and joint angles using a force plate analysis system or other instruments [14]. These biomechanical instruments can be used in laboratory settings, but they may not be applicable in clinical environments on a routine basis. The biomechanical instruments are costly, and the tests are time consuming. Moreover, use of the instruments may require highly trained personnel [15].

In contrast to biomechanical measures, nonbiomechanical measures in the form of clinical assessment tools or diagnostic tests are widely used in clinical settings [16]. Many clinical assessment tools are available to assess balance function in patients with SCI. Although clinical tools and tests are easier to administer than biomechanical tests [17], there is limited literature available regarding their reliability and validity. Therefore, the present review was conducted to systematically review articles reporting the validity and reliability of clinical instruments used to assess balance function in individuals with SCI.

\section{Methods}

A systematic review of diagnostic tests or clinical assessment tools was conducted according to PRISMA-DTA guidelines to the extent they apply [18]. Various databases including MEDLINE, Allied and Complementary Medicine (AMED), EMBASE for Excerpta Medica dataBASE, The Healthcare Management Information Consortium (HMIC), PsycINFO, Cumulative Index to Nursing and Allied Health Literature (CINAHL) from EBSCO, and Scopus were searched. The search terms "spinal cord (injury, damage, compression, ischemia, trauma, contusion, laceration, transaction, syndrome)," OR "spinal (fracture, subluxation, dislocation, injury, trauma)," OR "cervical vertebrae injuries," OR "lumbar vertebrae injuries," OR "thoracic vertebrae injuries," OR "SCI," or "paraplegia," OR "quadriplegia," OR "tetraplegia," AND "balance" OR "postural balance" OR "stability" OR "static balance" OR "dynamic balance" OR "walking balance" OR "sitting balance" OR "standing balance" OR "posture" OR "body equilibrium" OR "body posture" AND "clinical (assessment tools, instruments, scales, measurement tools, measures)" OR "nonbiomechanical (assessment tools, instruments, scales, measurement tools, measures)" OR "outcome (instruments, scales, tools, measures)" AND "reliability" OR "psychometric properties" OR "consistency" OR "validity" were used for the literature search, where AND and OR are logical operators. Truncations were used when they were appropriate.

The search results were imported into reference manager software. After removal of duplicates, 2 authors scanned the reference lists of the retrieved articles. Additionally, Google Scholar was searched to locate other relevant research articles. Research studies published in the English language from the earliest record to December 15, 2020, which reported validity and/or reliability of any of the clinical instrument used for the assessment of balance function in SCI individuals, were included. We excluded studies that reported psychometric properties of biomechanical measures such as force plate analysis, which are not used in clinical settings. Research articles that included paraplegic patients with causes other than SCI were excluded. Letter to editors, review articles, expert opinion, conference papers, brief communications, and commentaries were also excluded. 
Two reviewers independently screened the articles to exclude those research articles that did not fulfill the eligibility criteria. After excluding irrelevant studies, the full text of the remaining articles was studied by 2 independent reviewers and necessary data from all these studies were extracted. The COSMIN Risk of Bias checklist was used to assess risk of bias in the studies included $[19,20]$. Any disagreements between 2 reviewers were resolved by consensus with a third reviewer, who was consulted to confirm the extracted data. Discrepancies between the reviewers were resolved by consensus.

\section{Results}

A preliminary literature search identified 248 research articles; however, after removal of duplicates, only 93 studies remained. These 93 research articles were evaluated thoroughly for eligibility criteria, and only 16 articles fulfilled the inclusion criteria, while the remaining 77 articles were excluded (Figure 1). The articles reported validity and/or reliability of 10 clinical instruments including the Functional Reach Test (FRT), Berg balance scale (BBS), Mini-Balance Evaluation Systems Test (Mini-BESTest), Function in Sitting Test, T-Shirt Test, Motor Assessment Scale item 3, Sitting Balance Score, 5 Times Sit-to-Stand Test, Tinetti scale, and Sitting Balance Measure. Eleven articles assessed individual clinical instruments, while the remaining 5 articles assessed more than one clinical instrument.

Good-to-excellent test-retest reliability of the FRT was reported by 6 articles [21-26], while 1 article reported excellent inter-rater reliability (FRT) [27]. Construct, concurrent, and convergent validities of the FRT were reported by 1 article each [22, 23, 25]. Excellent inter-rater reliability of the BBS was reported by 2 articles [27, 28] and 1 article reported excellent intra-rater reliability [29], while 1 article

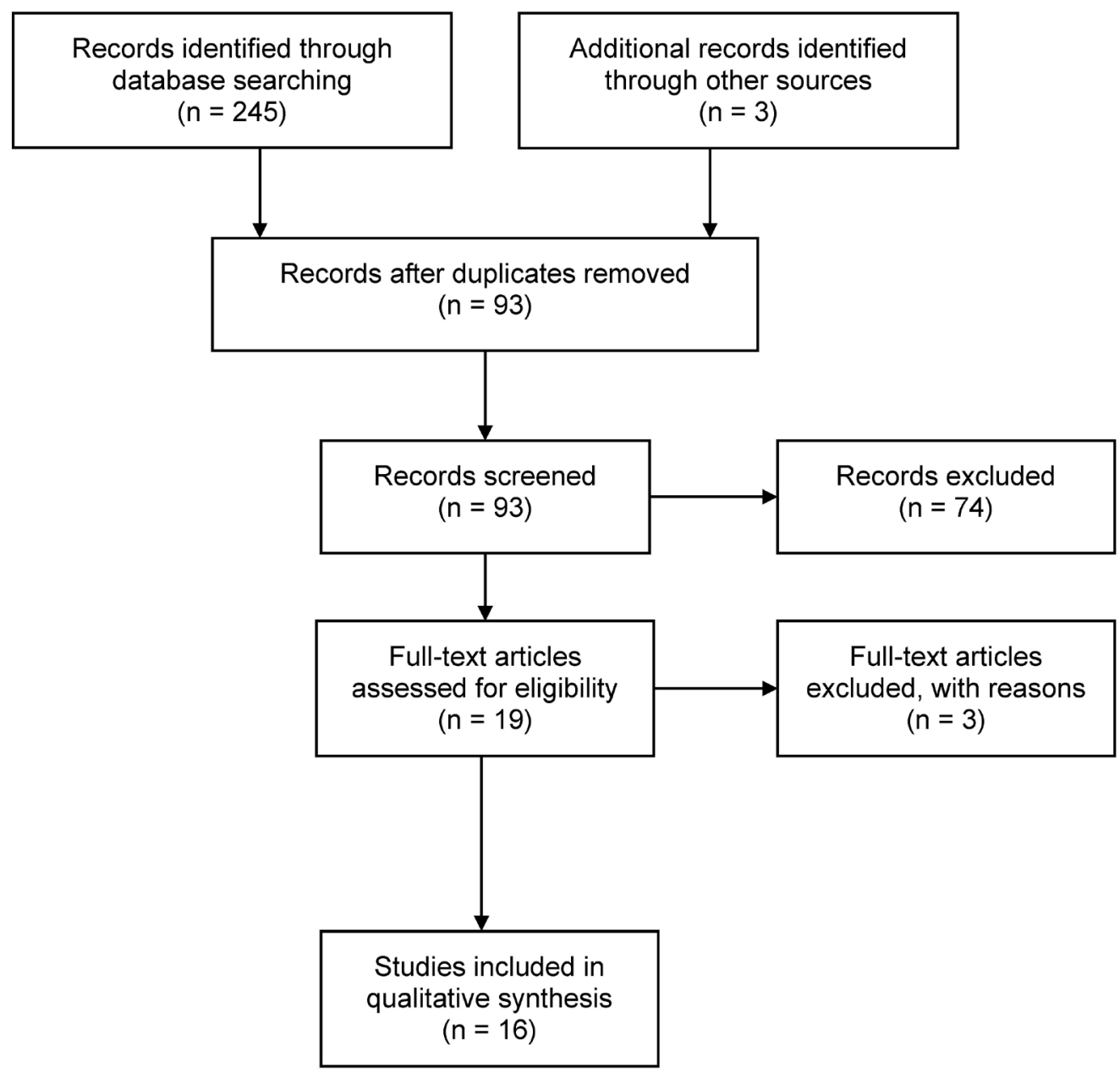

Figure 1. PRISMA flow diagram for record triage through the different phases of systematic review. 
reported high internal consistency [30]. Two articles reported concurrent validity of the BBS $[28,31]$ and 1 article reported construct validity [30]. The Mini-BESTest was assessed by 3 included articles [30, 32, 33]. These articles reported excellent test-retest reliability [32, 33], excellent inter-rater reliability [33], high internal consistency [30], and good concurrent, convergent [32], and construct validity [30] of the Mini-BESTest.

Excellent test-retest reliability and construct validity of the T-Shirt Test has been reported [22]. Excellent test-retest reliability, internal consistency, and concurrent validity of the Function in Sitting Test [34], good-to-excellent interrater reliability and criterion validity of the Motor Assessment Scale item 3 and Sitting Balance Score [35], excellent inter-rater reliability of the 5 Times Sit-to-Stand Test [27], good-to-excellent intra-rater reliability of the Tinetti scale [29], and high internal consistency and content validity of the Sitting Balance Measure [36] have been reported in 1 article each. Methodological quality varied across the studies (Table 1).

Table 1. Summary of studies that assessed the validity or reliability of 10 clinical instruments

\begin{tabular}{|c|c|c|c|c|c|}
\hline Article & $\begin{array}{l}\text { Methodological } \\
\text { quality }\end{array}$ & $\begin{array}{l}\text { Patient } \\
\text { characteristics }\end{array}$ & $\begin{array}{l}\text { Balance } \\
\text { measure }\end{array}$ & Validity & Reliability \\
\hline $\begin{array}{l}\text { Adegoke et al. } \\
{[21]}\end{array}$ & Inadequate & $\begin{array}{l}20 \text { adult } \\
\text { nonambulatory } \\
\text { patients with } \\
\text { SCI }\end{array}$ & FRT & & $\begin{array}{l}\text { Test-retest reliability was } \\
\text { assessed. ICC ranged from } 0.98 \\
\text { to } 0.99 \text { in individuals with diffe- } \\
\text { rent levels of injuries }\end{array}$ \\
\hline $\begin{array}{l}\text { Boswell-Ruys } \\
\text { et al. [22] }\end{array}$ & Doubtful & $\begin{array}{l}30 \text { adult pati- } \\
\text { ents with } \mathrm{SCl}\end{array}$ & $\begin{array}{l}\text { FRT and T-Shirt } \\
\text { Test }\end{array}$ & $\begin{array}{l}\text { Construct validity was assessed } \\
\text { using ASIA scores, level of injury, } \\
\text { and duration of injury. The tests } \\
\text { had good construct validity in } \\
\text { that they distinguished between } \\
\text { subjects with higher (C6-T7) and } \\
\text { lower (T8-L2) levels of injuries } \\
\text { and between patients with } \\
\text { acute and chronic SCI. The tests } \\
\text { correlated with ASIA motor and } \\
\text { sensory scores }\end{array}$ & $\begin{array}{l}\text { Test-retest reliability was } \\
\text { assessed. ICC for the reach test } \\
\text { ranged from } 0.80 \text { to } 0.89 \text { in } \\
\text { different directions while ICC } \\
\text { for T-Shirt Test ranged from } 0.85 \\
\text { to } 0.91 \text { with different tasks of } \\
\text { the test }\end{array}$ \\
\hline $\begin{array}{l}\text { Field-Fote and } \\
\text { Ray [23] }\end{array}$ & Adequate & $\begin{array}{l}32 \text { adult } \\
\text { patients with } \\
\text { motor incom- } \\
\text { plete SCI }\end{array}$ & FRT & $\begin{array}{l}\text { Concurrent validity was tested } \\
\text { with center of pressure excur- } \\
\text { sion. The correlation of forward, } \\
\text { backward, right and left reach } \\
\text { with center of pressure excursion } \\
\text { were } 0.71,0.72,0.95 \text {, and } 0.61 \text {, } \\
\text { respectively }\end{array}$ & $\begin{array}{l}\text { Test-retest reliability was } \\
\text { assessed. ICCs ranged from } 0.78 \\
\text { to } 0.95 \text { in different directions }\end{array}$ \\
\hline Lynch et al. [24] & Inadequate & $\begin{array}{l}30 \text { adult } \\
\text { patients with } \\
\text { motor com- } \\
\text { plete } \mathrm{SCl}\end{array}$ & FRT & & $\begin{array}{l}\text { Test-retest reliability was } \\
\text { assessed. ICC ranged from } 0.85 \\
\text { to } 0.94 \text { in patients with different } \\
\text { levels of injuries }\end{array}$ \\
\hline $\begin{array}{l}\text { Sprigle et al. } \\
\text { [25] }\end{array}$ & Doubtful & $\begin{array}{l}20 \text { adult } \\
\text { patients with } \\
\mathrm{SCl} \text { and injury } \\
\text { duration less } \\
\text { than } 6 \text { months }\end{array}$ & FRT & $\begin{array}{l}\text { Convergent validity was } \\
\text { assessed. The correlation of FRT } \\
\text { with activities of daily living } \\
\text { score was } 0.46\end{array}$ & $\begin{array}{l}\text { Test-retest reliability was } \\
\text { assessed. ICC was } 0.85\end{array}$ \\
\hline $\begin{array}{l}\text { Sprigle et al. } \\
\text { [26] }\end{array}$ & Inadequate & $\begin{array}{l}22 \text { adult } \\
\text { patients with } \\
\text { chronic } \mathrm{SCl}\end{array}$ & FRT & & $\begin{array}{l}\text { Test-retest reliability was } \\
\text { assessed. ICC was } 0.87\end{array}$ \\
\hline Srisim et al. [27] & Inadequate & $\begin{array}{l}25 \text { adult ambu- } \\
\text { latory patients } \\
\text { with } \mathrm{SCl}\end{array}$ & $\begin{array}{l}\text { BBS, FRT and } \\
\text { Five Times Sit- } \\
\text { to-Stand Test }\end{array}$ & & $\begin{array}{l}\text { Inter-rater reliability was } \\
\text { assessed. ICC for BBS, FRT, and } \\
\text { Five Times Sit-to-Stand Test were } \\
0.99,1.00 \text {, and } 0.99 \text {, respectively }\end{array}$ \\
\hline
\end{tabular}


Table 1. (Continued)

\begin{tabular}{|c|c|c|c|c|c|}
\hline Article & $\begin{array}{l}\text { Methodological } \\
\text { quality }\end{array}$ & $\begin{array}{l}\text { Patient cha- } \\
\text { racteristics }\end{array}$ & $\begin{array}{l}\text { Balance } \\
\text { measure }\end{array}$ & Validity & Reliability \\
\hline Wirz et al. [28] & Doubtful & $\begin{array}{l}42 \text { adult pati- } \\
\text { ents with } \mathrm{SCl}\end{array}$ & BBS & $\begin{array}{l}\text { Concurrent validity was assessed. } \\
\text { The correlation of BBS with SCIM } \\
\text { mobility score, Walking Index for } \\
\text { SCI, Falls Efficacy Scale, motor } \\
\text { scores, and number of falls was } \\
0.89,0.82,0.93,0.81,0.62 \text {, and } \\
0.17 \text {, respectively }\end{array}$ & $\begin{array}{l}\text { Inter-rater reliability was } \\
\text { assessed. ICC was } 0.953\end{array}$ \\
\hline $\begin{array}{l}\text { Tamburella et al. } \\
\text { [29] }\end{array}$ & Doubtful & $\begin{array}{l}23 \text { adult } \\
\text { patients with } \\
\text { incomplete SCl }\end{array}$ & $\begin{array}{l}\text { BBS, Tinetti } \\
\text { (total), Tinetti } \\
\text { (equilibrium), } \\
\text { Tinetti } \\
\text { (locomotion) }\end{array}$ & & $\begin{array}{l}\text { Intra-rater reliability was } \\
\text { assessed. ICC for BBS, Tinetti } \\
\text { (total), Tinetti (equilibrium), and } \\
\text { Tinetti (locomotion) were } 0.97 \text {, } \\
0.22,0.87 \text {, and } 0.78 \text {, respectively }\end{array}$ \\
\hline $\begin{array}{l}\text { Jørgensen et al. } \\
\text { [30] }\end{array}$ & Adequate & $\begin{array}{l}46 \text { adult } \\
\text { patients with } \\
\text { chronic SCl }\end{array}$ & $\begin{array}{l}\text { BBS and Mini- } \\
\text { BESTest }\end{array}$ & $\begin{array}{l}\text { Construct validity was assessed. } \\
\text { Strong correlations between } \\
\text { both scales }(r=0.90) \text { and } \\
\text { between both scales and Timed } \\
\text { Up and Go }(r>0.70), \text { SCIM } \\
\text { mobility scores }(r>0.80) \text {, and } \\
\text { 10-Meter Walk Test }(r>0.80) \\
\text { support high construct validity }\end{array}$ & $\begin{array}{l}\text { Internal consistency was } \\
\text { assessed. Cronbach } \alpha \text { for BBS } \\
\text { was } 0.94 \text { while } \alpha \text { for Mini-BESTest } \\
\text { was } 0.95\end{array}$ \\
\hline $\begin{array}{l}\text { Lemay and } \\
\text { Nadeau [31] }\end{array}$ & Inadequate & $\begin{array}{l}32 \text { adult } \\
\text { patients with } \\
\text { motor incom- } \\
\text { plete } \mathrm{SCl}\end{array}$ & BBS & $\begin{array}{l}\text { Concurrent validity was assessed. } \\
\text { The correlation of BBS with } \\
\text { 2-minute walk test, Walking } \\
\text { Index for } \mathrm{SCl}, 10 \text {-Meter Walk Test, } \\
\text { and Timed Up and Go were } 0.78 \text {, } \\
0.81,0.79 \text {, and }-0.81 \text {, respec- } \\
\text { tively, while its correlation with } \\
\text { Functional Ambulation Inventory } \\
\text { (SCI-FAl) ranged } 0.71-0.74\end{array}$ & \\
\hline Chan et al. [32] & Adequate & $\begin{array}{l}21 \text { adult } \\
\text { patients with } \\
\text { chronic motor } \\
\text { incomplete SCl }\end{array}$ & Mini-BESTest & $\begin{array}{l}\text { Concurrent and convergent vali- } \\
\text { dity was tested with measures } \\
\text { of center of pressure velocity } \\
\text { during eye open and eye closed } \\
\text { standing and lower extremity } \\
\text { muscle strength, respectively. } \\
\text { The correlation of Mini-BESTest } \\
\text { scores with center of pressure } \\
\text { velocity during standing with } \\
\text { eye open ranged from - } 0.48 \text { to } \\
\text {-0.76 and during standing with } \\
\text { eye closed ranged from - } 0.04 \text { to } \\
0.07 \text {. The correlation of Mini- } \\
\text { BESTest scores with lower extre- } \\
\text { mity muscle strength was } 0.73\end{array}$ & $\begin{array}{l}\text { Test-retest reliability was } \\
\text { assessed. ICC for the total score } \\
\text { of Mini-BESTest was } 0.98\end{array}$ \\
\hline Roy et al. [33] & Very good & $\begin{array}{l}23 \text { adult pati- } \\
\text { ents with } \mathrm{SCl}\end{array}$ & Mini-BESTest & & $\begin{array}{l}\text { Test-retest and inter-rater relia- } \\
\text { bility was assessed. } \\
\text { ICC for test-retest and inter-rater } \\
\text { reliability were } 0.94 \text { and } 0.96 \text {, } \\
\text { respectively }\end{array}$ \\
\hline Abou et al. [34] & Adequate & $\begin{array}{l}26 \text { adult } \\
\text { nonambulatory } \\
\text { patients with } \\
\text { chronic SCl }\end{array}$ & $\begin{array}{l}\text { Function in } \\
\text { Sitting Test }\end{array}$ & $\begin{array}{l}\text { Concurrent validity was tested } \\
\text { with modified FRT (forward } \\
\text { and lateral) and posturography } \\
\text { assessment (virtual time }\end{array}$ & $\begin{array}{l}\text { Test-retest reliability and } \\
\text { internal consistency was } \\
\text { assessed. }\end{array}$ \\
\hline
\end{tabular}


Table 1. (Continued)

\begin{tabular}{|c|c|c|c|c|c|}
\hline Article & $\begin{array}{l}\text { Methodological } \\
\text { quality }\end{array}$ & $\begin{array}{l}\text { Patient cha- } \\
\text { racteristics }\end{array}$ & $\begin{array}{l}\text { Balance } \\
\text { measure }\end{array}$ & Validity & Reliability \\
\hline & & & & $\begin{array}{l}\text { to contact). The correlation of } \\
\text { function in sitting test with } \\
\text { lateral reach was } 0.64 \text { while its } \\
\text { correlation with forward reach } \\
\text { and virtual time to contact was } \\
0.16 \text { and } 0.23 \text {, respectively. }\end{array}$ & $\begin{array}{l}\text { ICC was } 0.95 \text { Cronbach } \alpha \text { was } \\
0.81\end{array}$ \\
\hline $\begin{array}{l}\text { Jørgensen et al. } \\
\text { [35] }\end{array}$ & Adequate & $\begin{array}{l}48 \text { adult pati- } \\
\text { ents with } \mathrm{SCl}\end{array}$ & $\begin{array}{l}\text { Motor Assess- } \\
\text { ment Scale item } \\
3 \text { and Sitting } \\
\text { Balance Score }\end{array}$ & $\begin{array}{l}\text { Criterion validity was assessed. } \\
\text { The correlation between the } \\
\text { scales were in relation to } \\
\text { neurological injury level } \\
(r=0.19-0.51) \text {, extent of } \\
\text { injury }(r=0.57-0.68) \text {, functio- } \\
\text { nal independence measure } \\
(r=0.13-0.68) \text {, and } 5 \text { additional } \\
\text { mobility and locomotor items } \\
(r=0.10-0.49)\end{array}$ & $\begin{array}{l}\text { Inter-rater reliability was } \\
\text { assessed. For Motor Assess- } \\
\text { ment Scale item } 3 k \text { with linear } \\
\text { weights }\left(k_{w}\right) \text { ranged from } 0.83 \text { to } \\
0.91 \text { with different raters while } \\
\text { for Sitting Balance Score } k \text { with } \\
\text { linear weights }\left(k_{w}\right) \text { ranged from } \\
0.69 \text { to } 0.96 \text { with different raters }\end{array}$ \\
\hline $\begin{array}{l}\text { Wadhwa and } \\
\text { Aikat [36] }\end{array}$ & Doubtful & $\begin{array}{l}30 \text { adult pati- } \\
\text { ents with } \mathrm{SCl}\end{array}$ & $\begin{array}{l}\text { Sitting Balance } \\
\text { Measure }\end{array}$ & $\begin{array}{l}\text { Content validity of Sitting } \\
\text { Balance Measure was establis- } \\
\text { hed through qualitative review } \\
\text { by experts and by calculating } \\
\text { content validity ratio. }\end{array}$ & $\begin{array}{l}\text { Internal consistency was } \\
\text { assessed. Cronbach } \alpha \text { was } 0.96\end{array}$ \\
\hline
\end{tabular}

ASIA, American Spinal Injury Association; BBS, Berg Balance Scale, FRT, Functional Reach Test; ICC, intraclass correlation coefficient; Mini-BESTest, Mini-Balance Evaluation Systems Test; SCI, Spinal Cord Injury; SCIM, Spinal Cord Independence Measure.

\section{Discussion}

SCI and its sequelae in the form of paralysis and impaired sensations result in a wide range of physical and psychological disorders [37]. SCI usually results in lifelong disability and rehabilitation interventions aim to minimize complications and maximize independence of individuals with SCI [38]. Mobility training, transfer training, wheelchair maneuverability, gait training, and balance training are important components of rehabilitation for individuals with SCI [39]. Among these components, rehabilitation specialists always give more focus to balance training because without good balance function, patients with SCI cannot achieve maximum independence [40]. Almost all other rehabilitation components depend on proper postural stability and that is why clinicians start balance training from the first day of rehabilitation and continue this training until the rehabilitation protocols are complete [41].

Many outcome measures are available to assess balance function in patients with neurological disorders. These outcome measures range from highly complicated biomechanical measures requiring sophisticated instrumentation to simple and easily administered clinical tests [42]. Owing to the complexity and cost of biomechanical measures, they are seldom used in clinical practice; however, they are frequently used by researchers. By contrast, clinical tests are frequently used by clinicians to assess balance function [43]. A variety of outcome measures is used in clinical practice, each of which assesses different aspects of balance function [44]. Ten clinical instruments that can be used to assess balance function of individuals with SCI in clinical settings were identified in the current systematic review. These include the FRT, BBS, MiniBESTest, Function in Sitting Test, T-Shirt Test, Motor Assessment Scale item 3, Sitting Balance Score, 5 Times Sit-to-Stand Test, Tinetti scale, and Sitting Balance Measure. Most of these clinical instruments are not specific to individuals with SCI, and they can be used to assess balance function in the elderly and in patients with other neurological diseases [45].

The present search retrieved 16 research articles that reported validity and/or reliability of clinical instruments to assess balance function in patients with SCI. This clearly highlights the scarcity of literature regarding these clinical instruments. The instruments are widely used in clinical settings; however, the limited literature shows that they have not received robust attention from researchers. There is a need for high quality research regarding the validity and reliability of these clinical instruments because without high quality evidence, clinicians may not be confident to use these clinical instruments. The present review systematically evaluated available literature that assessed the clinical instruments used to assess balance function in patients with SCI. 
FRT, BBS, and Mini-BESTest are the most commonly used clinical instruments used to assess balance function [27, $30]$ and can be used for a variety of conditions. Patients with musculoskeletal disorders, such as chronic low back pain, and patients with neurological conditions, such as stroke, can be assessed with these instruments, which can be used in the geriatric population [46]. Most articles in current review reported good-to-excellent reliability and good validity of the FRT, BBS, and Mini-BESTest to assess balance function in patients with SCI. These clinical instruments provide valid and reliable outcome measures for assessing balance in patients with balance disorders [47, 48]. Apart from these 3 instruments, the validity and reliability of other clinical instruments are rarely described in the literature. The available literature reported that the T-Shirt Test has excellent test-retest and construct validity, while the Function in the Sitting Test has excellent test-retest reliability, internal consistency, and concurrent validity.

Despite that the current review assimilates the available literature regarding outcome measures used in clinical settings to assess balance function in patients with SCI, it has some limitations. First, due to heterogeneity in the data, it was not feasible to conduct a meta-analysis and so only descriptive results are presented. Second, due to the scarce and limited literature it was difficult to draw firm conclusions regarding the reliability and validity of various clinical instruments. The protocols used to conduct the systematic review were not registered, for example in PROSPERO [49].

\section{Conclusion}

Few research studies determined the reliability and validity of clinical instruments in the assessment of balance function in SCI individuals. From the available literature, it appears that FRT, BBS, and Mini-BESTest are valid and reliable clinical instruments for the assessment of balance function in individuals with SCI. Due to scarcity of literature regarding the validity and reliability of other clinical instruments, no firm conclusions can be drawn regarding their use in clinical settings. Large multicenter studies are recommended to determine the validity and reliability of clinical instruments.

Author contributions. AA, HD, and SS contributed substantially to the conception and design of the study. AA and IU contributed substantially to the acquisition of data, and all authors contributed substantially to its analysis and interpretation. AA drafted the manuscript, and HD, IU, and SS critically revised it for important intellectual content. All authors approved the final version submitted for publication and take responsibility for statements made in the published article.
Acknowledgments. This article forms part of the $\mathrm{PhD}$ thesis of the principle author. We did not receive any specific grant for this research from any funding agency in the public, commercial, or not-for-profit sectors.

Conflicts of interest statement. All authors have completed and submitted an International Committee of Medical Journal Editors Uniform Disclosure Statement Form for Potential Conflicts of Interest. None of the authors has any conflict of interest to disclose in relation to the published article.

Data sharing statement. All data is presented in the present article. No additional data sets were generated or analyzed during the present study. The present systematic review is based on the references cited.

\section{References}

[1] Chou CH, Hwang CL, Wu YT. Effect of exercise on physical function, daily living activities, and quality of life in the frail older adults: a meta-analysis. Arch Phys Med Rehabil. 2012; 93:237-44.

[2] Wulf G, Shea C, Lewthwaite R. Motor skill learning and performance: a review of influential factors. Med Educ. 2010; 44:75-84.

[3] Winter DA, Patla AE, Ishac M, Gage WH. Motor mechanisms of balance during quiet standing. J Electromyogr Kinesiol. 2003; 13:49-56.

[4] de Kam D, Roelofs JMB, Bruijnes AKBD, Geurts ACH, Weerdesteyn V. The next step in understanding impaired reactive balance control in people with stroke: the role of defective early automatic postural responses. Neurorehabil Neural Repair. 2017; 31:708-16.

[5] Alves J, Santos A. Virtual reality therapy for balance training in aging and neurological disorders. J Adv Neurosci Res. 2016; 3:1-8.

[6] Hardin EC, Kobetic R, Triolo RJ. Ambulation and spinal cord injury. Phys Med Rehabil Clin N Am. 2013; 24:355-70.

[7] Jannings W, Pryor J. The experiences and needs of persons with spinal cord injury who can walk. Disabil Rehabil. 2012; 34:1820-6.

[8] Nas K, Yazmalar L, Şah V, Aydın A, Öneş K. Rehabilitation of spinal cord injuries. World J Orthop. 2015; 6:8-16.

[9] Harkema SJ, Schmidt-Read M, Lorenz DJ, Edgerton VR, Behrman AL. Balance and ambulation improvements in individuals with chronic incomplete spinal cord injury using locomotor training-based rehabilitation. Arch Phys Med Rehabil. 2012; 93:1508-17.

[10] Emerich L, Parsons KC, Stein A. Competent care for persons with spinal cord injury and dysfunction in acute inpatient rehabilitation. Top Spinal Cord Inj Rehabil. 2012; 18:149-66.

[11] van Hedel HJA, Dietz V. Rehabilitation of locomotion after spinal cord injury. Restor Neurol Neurosci. 2010; 28:123-34.

[12] Mancini M, Horak FB. The relevance of clinical balance assessment tools to differentiate balance deficits. Eur J Phys Rehabil Med. 2010; 46:239-48.

[13] Arora T, Oates A, Lynd K, Musselman KE. Current state of balance assessment during transferring, sitting, standing and walking activities for the spinal cord injured population: a systematic review. J Spinal Cord Med. 2020; 43:10-23. 
[14] Chaudhry H, Bukiet B, Ji Z, Findley T. Measurement of balance in computer posturography: comparison of methods-a brief review. J Bodyw Mov Ther. 2011; 15:82-91.

[15] Clark RA, Bryant AL, Pua Y, McCrory P, Bennell K, Hunt M. Validity and reliability of the Nintendo Wii Balance Board for assessment of standing balance. Gait Posture. 2010; 31:307-10.

[16] Alexander MS, Anderson KD, Biering-Sorensen F, Blight AR, Brannon R, Bryce TN, et al. Outcome measures in spinal cord injury: recent assessments and recommendations for future directions. Spinal Cord. 2009; 47:582-91.

[17] Lam T, Noonan VK, Eng JJ; SCIRE Research Team. A systematic review of functional ambulation outcome measures in spinal cord injury. Spinal Cord. 2008; 46:246-54.

[18] Salameh JP, Bossuyt PM, McGrath TA, Thombs BD, Hyde CJ, Macaskill P, et al. Preferred reporting items for systematic review and meta-analysis of diagnostic test accuracy studies (PRISMA-DTA): explanation, elaboration, and checklist. BMJ. 2020; 370:m2632. doi: 10.1136/bmj.m2632

[19] Mokkink LB, de Vet HCW, Prinsen CAC, Patrick DL, Alonso J, Bouter LM, Terwee CB. COSMIN Risk of Bias checklist for systematic reviews of Patient-Reported Outcome Measures. Qual Life Res. 2018; 27:1171-9.

[20] Prinsen CAC, Mokkink LB, Bouter LM, Alonso J, Patrick DL, de Vet HCW, Terwee CB. COSMIN guideline for systematic reviews of patient-reported outcome measures. Qual Life Res. 2018; 27:1147-57.

[21] Adegoke BOA, Ogwumike OO, Olatemiju A. Dynamic balance and level of lesion in spinal cord injured patients. Afr J Med Med Sci. 2002; 31:357-60.

[22] Boswell-Ruys CL, Sturnieks DL, Harvey LA, Sherrington C, Middleton JW, Lord SR. Validity and reliability of assessment tools for measuring unsupported sitting in people with a spinal cord injury. Arch Phys Med Rehabil. 2009; 90:1571-77.

[23] Field-Fote EC, Ray SS. Seated reach distance and trunk excursion accurately reflect dynamic postural control in individuals with motor-incomplete spinal cord injury. Spinal Cord. 2010; 48:745-49.

[24] Lynch SM, Leahy P, Barker SP. Reliability of measurements obtained with a modified functional reach test in subjects with spinal cord injury. Phys Ther. 1998; 78:128-33.

[25] Sprigle S, Maurer C, Holowka M. Development of valid and reliable measures of postural stability. J Spinal Cord Med. 2007; 30:40-49.

[26] Sprigle S, Wootten M, Sawacha Z, Thielman G. Relationships among cushion type, backrest height, seated posture, and reach of wheelchair users with spinal cord injury. J Spinal Cord Med. 2003; 26:236-43.

[27] Srisim K, Saengsuwan J, Amatachaya S. Functional assessments for predicting a risk of multiple falls in independent ambulatory patients with spinal cord injury. J Spinal Cord Med. 2015; 38:439-45.

[28] Wirz M, Muller R, Bastiaenen C. Falls in persons with spinal cord injury: validity and reliability of the Berg Balance Scale. Neurorehabil Neural Repair. 2010; 24:70-7.

[29] Tamburella F, Scivoletto G, Iosa M, Molinari M. Reliability, validity, and effectiveness of center of pressure parameters in assessing stabilometric platform in subjects with incomplete spinal cord injury: A serial cross-sectional study. J Neuroeng Rehabil. 2014; 11:86-98.

[30] Jørgensen V, Opheim A, Halvarsson A, Franzén E, Roaldsen KS. Comparison of the Berg Balance Scale and the Mini-BESTest for assessing balance in ambulatory people with spinal cord injury: validation study. Phys Ther. 2017; 97:677-87.
[31] Lemay JF, Nadeau S. Standing balance assessment in ASIA D paraplegic and tetraplegic participants: concurrent validity of the Berg Balance Scale. Spinal Cord. 2010; 48: 245-50.

[32] Chan K, Unger J, Lee JW, Johnston G, Constand M, Masani K, Musselman KE. Quantifying balance control after spinal cord injury: reliability and validity of the mini-BESTest. J Spinal Cord Med. 2019; 42(suppl 1):141-8.

[33] Roy A, Higgins J, Nadeau S. Reliability and minimal detectable change of the mini-BESTest in adults with spinal cord injury in a rehabilitation setting. Physiother Theory Pract. 2021: 37:126-34.

[34] Abou L, Sung JH, Sosnoff JJ, Rice LA. Reliability and validity of the function in sitting test among non-ambulatory individuals with spinal cord injury. J Spinal Cord Med. 2020; 43:846-53.

[35] Jørgensen V, Elfving B, Opheim A. Assessment of unsupported sitting in patients with spinal cord injury. Spinal Cord. 2011; 49:838-43.

[36] Wadhwa G, Aikat R. Development, validity and reliability of the 'Sitting Balance Measure' (SBM) in spinal cord injury. Spinal Cord. 2016; 54:319-23.

[37] Anderson KD. Targeting recovery: priorities of the spinal cord-injured population. J Neurotrauma. 2004; 21:1371-1383.

[38] Amatachaya S, Wannapakhe J, Arrayawichanon P, Siritarathiwat W, Wattanapun P. Functional abilities, incidences of complications and falls of patients with spinal cord injury 6 months after discharge. Spinal Cord. 2011; 49:520-4.

[39] Kirshblum SC, Priebe MM, Ho CH, Scelza WM, Chiodo AE, Wuermser LA. Spinal cord injury medicine. 3. Rehabilitation phase after acute spinal cord injury. Arch Phys Med Rehabil. 2007; 88(3 Suppl 1):S62-70

[40] Barbeau H, Nadeau S, Garneau C. Physical determinants, emerging concepts, and training approaches in gait of individuals with spinal cord injury. J Neurotrauma. 2006; 23:571-85.

[41] Tamburella F, Scivoletto G, Molinari M. Balance training improves static stability and gait in chronic incomplete spinal cord injury subjects: a pilot study. Eur J Phys Rehabil Med. 2013; 49:353-64.

[42] Nardone A, Schieppati M. The role of instrumental assessment of balance in clinical decision making. Eur J Phys Rehabil Med. 2010; 46:221-37.

[43] Yelnik A, Bonan I. Clinical tools for assessing balance disorders. Neurophysiol Clin. 2008; 38:439-45.

[44] Noohu MM, Dey AB, Hussain ME. Relevance of balance measurement tools and balance training for fall prevention in older adults. J Clin Gerontol Geriatr. 2014; 5:31-5.

[45] Sibley KM, Straus SE, Inness EL, Salbach NM, Jaglal SB. Clinical balance assessment: perceptions of commonly-used standardized measures and current practices among physiotherapists in Ontario, Canada. Implement Sci. 2013; 8:33. doi: 10.1186/1748-5908-8-33

[46] Park E-Y, Kim W-H. Correlation of Berg balance scale and functional reach test. Phys Ther Korea. 2007; 14:28-34.

[47] Moore JL, Potter K, Blankshain K, Kaplan SL, O’Dwyer LC, Sullivan JE. A core set of outcome measures for adults with neurologic conditions undergoing rehabilitation: a clinical practice guideline. J Neurol Phys Ther. 2018; 42:174-220.

[48] Tyson SF, Connell LA. How to measure balance in clinical practice. A systematic review of the psychometrics and clinical utility of measures of balance activity for neurological conditions. Clin Rehabil. 2009; 23:824-40.

[49] Page M), Shamseer L, Tricco AC. Registration of systematic reviews in PROSPERO: 30,000 records and counting. Syst Rev. 2018; 7:32. doi: 10.1186/s13643-018-0699-4 